\title{
Reimplantation of ring avulsion amputation of finger: intraoperative challenges and rehabilitation outcomes
}

\author{
Yinan Zhu (ㅁ) , Lachlan Currie
}

Plastic Surgery, University Hospitals Plymouth NHS Trust, Plymouth, UK

Correspondence to Yinan Zhu; yinan.zhu@nhs.net

Accepted 10 October 2021

\section{DESCRIPTION}

A 14-year-old teenager presented with a ring avulsion amputation of his right ring finger at the head of the proximal phalange in November 2020 as shown in figure 1 . This injury was sustained as his metal ring was caught on a spike while jumping from a 12-feet school fence. On arrival, the amputated digit was wrapped in a saline $0.9 \%$ soaked gauze and then placed into a plastic bag, which was immersed in a container with water and ice. ${ }^{1}$ With a cold ischaemic time of less than 2 hours and following discussion with the patient and his family, replantation was opted for.

Intraoperatively, the proximal phalanx was reduced and fixed in position with a single Kirschner wire (K-wire). Fortunately, due to the fracture orientation, a second antirotational K-wire was not needed. It was noted that the flexor digitorum profundus (FDP) tendon was avulsed at the insertion point of the distal phalanx and the flexor digitorum superficialis (FDS) tendon was avulsed from the forearm with muscle cuff visible. The distal aspect of the FDS was transferred to the FDP tendon as reinsertion of the FDP would be too disruptive to blood supply. The flexor tendon repair was performed with a Pulvertaft weave technique. As for the extensor tendon, the central slip was repaired with a $4-0$ prolene mattress suture. The distal digital radial artery and nerve were avulsed and not viable, so their proximal ends were used as crossovers to connect to the digital ulnar artery (10-0 nylon) and nerve (8-0 nylon), respectively. Two dorsal veins were repaired with $10-0$ nylon for venous drainage. A split skin graft (SSG) was taken from his right thigh to cover the skin defect following skin closure. Postprocedure, the patient was observed closely on the ward for 5 days. His finger was well perfused, with good take of the SSG on discharge.

His follow-up protocol was as per the British Society for Surgery of the Hand (BSSH) standards of care, with regular support from hand therapists. $^{2}$ His hand therapy regime included support therapy early on while the digit was immobilised, subsequently moving to block and strengthening exercises after about 2 months. At the 1-month follow-up, the proximal interphalangeal joint (PIPJ) was stiff. Overgranulation was also noted at the graft site, which was treated effectively with cautery (figure 1). At 6 months, he demonstrated good passive flexion at the PIPJ down to $70^{\circ}$ with a spongey end point. At 9 months, the replanted finger was sensate to temperature and the PIPJ had full range of passive movement. Active flexion was still poor and he is scheduled for flexor tendon tenolysis \pm shortening of tendon to further improve function. Concurrently, he is also undergoing therapy with regards to the psychological effects of this trauma.

Amputated digits are devoid of muscles and can survive up to 12 hours of cold ischemia. ${ }^{3} \mathrm{~A}$ common error in the preservation of an amputated part is to expose it to ice directly, which may cause a cold injury. Proper preservation of the amputated digit at the scene (wrapped with moist gauze,
A) Check for updates

(c) BMJ Publishing Group Limited 2021. No commercial re-use. See rights and permissions. Published by BMJ.

To cite: Zhu Y, Currie L. BMJ Case Rep 2021;14:e245994. doi:10.1136/bcr-2021-

245994

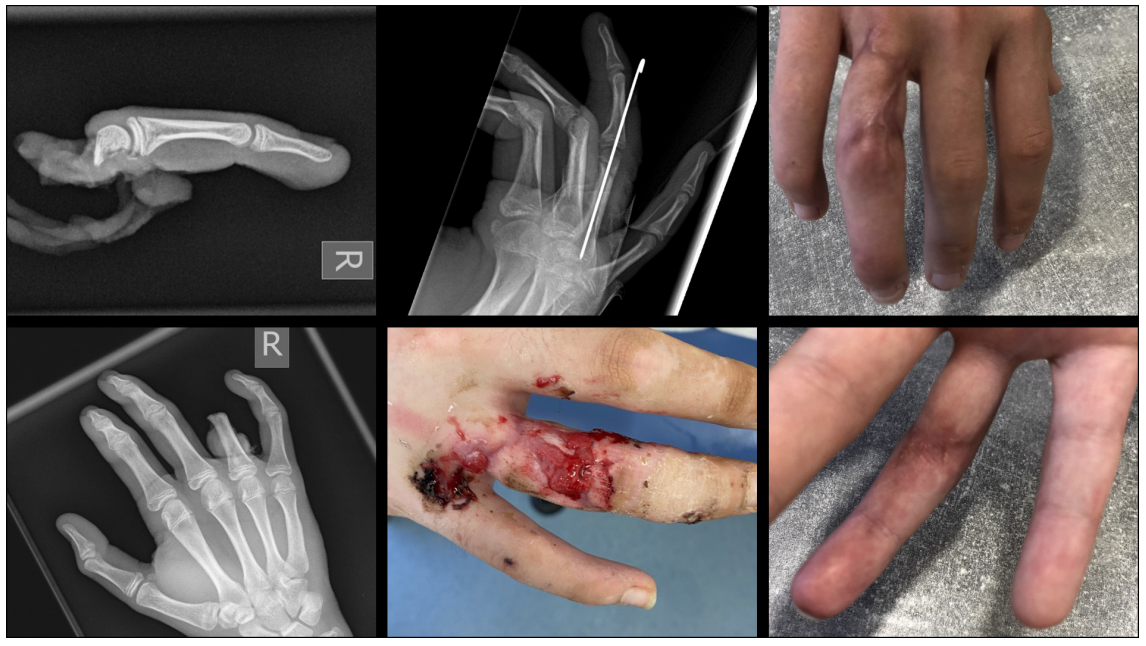

Figure 1 Top and bottom left: X-ray showing an avulsion amputation of the right ring finger. Top middle: postoperative K-wire position. Bottom middle: right index finger 6 weeks postoperation, showing healing graft and some overgranulation tissue. Top and bottom right: right index finger 6 months postoperation. 
placed in a plastic bag floated in water and ice) increases its viability. ${ }^{1}$

However, controversy still exists in the management of ring avulsion injuries. This patient has a class IVp injury (amputation proximal to the FDS insertion) as per the Kay classification modified by Adani, ${ }^{4}$ and many would not choose to attempt replantation of the digit ${ }^{5}$ given the risk of poor functional outcomes even with successful revascularisation. However, children do have greater healing potential and have better overall outcomes

\section{Patient's perspective}

Everyone was respectful, caring and overall it was a good job. The various departments involved in my care were amazing.

\section{Learning points}

- Proper preservation of an amputated digit (wrapped with moist gauze, placed in a plastic bag floated in water and ice) increases its viability.

- Replantation of a single digit in a child with the amputation proximal to the flexor digitorum superficialis insertion can have good outcomes.

- Surgical flexibility and working around limitations given the extent of the amputation can contribute to successful replantation.

- Regardless of functional outcomes, replantation preserves the cosmetic appearance of the digit and this can help with the associated traumatic psychological distress. postoperatively compared with adults. ${ }^{6}$ While the patient is satisfied with the surgical outcomes including the improving mobility of the replanted digit, he is also grateful for the emotional relief that this has brought with the preserved cosmetic outcome of his finger.

An amputation of a digit can be life changing for a teenager, and successful replantation not only boosts the prospect of improved function but also alleviates psychological distress and aids recovery from the associated emotional trauma. ${ }^{3}$

Contributors YZ drafted the manuscript; LC reviewed and edited the text and images. All authors approved the final version of the manuscript to be published.

Funding The authors have not declared a specific grant for this research from any funding agency in the public, commercial or not-for-profit sectors.

Competing interests None declared.

Patient consent for publication Consent obtained from parent(s)/guardian(s)

Provenance and peer review Not commissioned; externally peer reviewed.

\section{ORCID iD}

Yinan Zhu http://orcid.org/0000-0002-1034-8882

\section{REFERENCES}

1 Partlin MM, Chen J, Holdgate A. The preoperative preservation of amputated digits: an assessment of proposed methods. J Trauma 2008;65:127-31.

2 BSSH. Revascularisation/Replantation, 2021. Available: https://www.bssh.ac.uk/ userfiles/pages/files/professionals/Trauma standards/6 Revascularisation final.pdf

3 Michalko KB, Bentz ML. Digital replantation in children. Crit Care Med 2002;30:S444-7.

4 Adani R, Marcoccio I, Castagnetti C, et al. Long-term results of replantation for complete ring avulsion amputations. Ann Plast Surg 2003;51:564-8.

5 Adani R, Pataia E, Tarallo L, et al. Results of replantation of 33 ring avulsion amputations. J Hand Surg Am 2013:38:947-56.

6 Berlin NL, Tuggle CT, Thomson JG, et al. Digit replantation in children: a nationwide analysis of outcomes and trends of 455 pediatric patients. Hand 2014;9:244-52.

Copyright 2021 BMJ Publishing Group. All rights reserved. For permission to reuse any of this content visit https://www.bmj.com/company/products-services/rights-and-licensing/permissions/

BMJ Case Report Fellows may re-use this article for personal use and teaching without any further permission.

Become a Fellow of BMJ Case Reports today and you can:

- Submit as many cases as you like

- Enjoy fast sympathetic peer review and rapid publication of accepted articles

- Access all the published articles

- Re-use any of the published material for personal use and teaching without further permission

Customer Service

If you have any further queries about your subscription, please contact our customer services team on +44 (0) 2071111105 or via email at support@bmj.com.

Visit casereports.bmj.com for more articles like this and to become a Fellow 